\title{
An historical perspective on cell mechanics
}

\author{
Andrew E. Pelling • Michael A. Horton
}

Received: 30 September 2007 /Revised: 12 November 2007 / Accepted: 15 November 2007 /Published online: 7 December 2007

(C) Springer-Verlag 2007

\begin{abstract}
The physical properties of the protoplasm have long been of interest, and today, several intricate methods, including atomic force microscopy, have been employed in studies of cellular mechanics. However, many current concepts and experimental approaches actually have their beginnings over 300 years ago. Unfortunately, these pioneering studies have been all but forgotten. In this paper, we have reviewed some of the early literature on cellular mechanics to place modern work within an historical framework. It is clear that with current nanoscience approaches, modern experiments employing cell indentation, manipulation, particle rheology and micro- or nano-needle poking are now quantifying mechanical properties which were only qualitatively described 100 years ago. Aside from the variety of approaches our predecessors have employed to understand cellular mechanics, we feel an understanding of the past will help to propel nanoscience into the future. As nanophysiology and nanomedicine are developing, we as a community should take time to consider the early roots of these fields.
\end{abstract}

Keywords Protoplasm - Cell mechanics · Elasticity · Viscoelasticity · Viscosity · Atomic force microscopy

\section{Introduction}

"Much excellent research has been done with a test tube and a Bunsen burner, but certain problems cannot be

\footnotetext{
A. E. Pelling $(\bowtie) \cdot$ M. A. Horton $(\bowtie)$

The London Centre for Nanotechnology,

Centre for Nanomedicine, University College London,

17-19 Gordon Street,

London WC1H 0AH, UK

e-mail: a.pelling@ucl.ac.uk

e-mail: m.horton@ucl.ac.uk
}

successfully attacked without the aid of intricate apparatus. It is the latter type of research, in so far as it applies to studies on the physical properties of protoplasm with which this report deals." (Seifriz, 1937 [1]).

In the late seventeenth century, the likes of Robert Hooke and Antony van Leeuwenhoek were using simple optical microscopes to peer down into a tiny living universe in which fluid and cellular motion appeared to be extreme. In a letter [2] written on Christmas Day, 1702, van Leeuwenhoek describes what may be the first observations of the ciliate Vorticella, "In structure these little animals were fashioned like a bell, and at the round opening they made such a stir, that the particles in the water thereabout were set in motion thereby... which sight I found mightily diverting." The appearance of motion in this tiny world was not lost on these early observers. Brownian motion of particles and organelles inside living cells have been commonly reported $[3,4]$. It was also conjectured that it may be possible to estimate viscosity by measuring these quantities. Although the tools were not available in the seventeenth century to perform accurate micro-rheology and nano-indentation experiments, many of the philosophical ideas and concepts we deal with today had their beginnings over 300 years ago. Moreover, the technological basis and understanding of cell and tissue mechanics has its foundation in the rapid industrialisation of the nineteenth century- the need for a thorough understanding of mechanical and structural testing and theory (indentation, beam bending, the Hertz model) of macroscale materials such as engines, boats and bridges [5]. This in turn reflected an earlier silvan economy - indeed, understanding the adaptation, structure and material properties of different woods (oak versus pine) preceded and defined our concept of tissue adaptation (for example, Wolff's law as applied to the skeleton) [5]. At the end of the nineteenth century, the mechanical properties of 
living cells were experimentally examined and analyzed using a variety of techniques based upon these macroscale engineering mechanics. Today, over a century later, our current nanoscale testing and modelling of biological materials is still fundamentally based on nineteenth-century practices [6-8].

The living cell is a universe unto itself. It was quickly recognized that the cellular universe is vastly complex and always experiencing turbulent forces and dynamics within the protoplasm which were somehow related to function. In this historical review, we will present work from very early studies involving the mechanical motion and properties of living cells. We will attempt to describe these studies in relation to modern approaches including, but not limited to, atomic force microscopy (AFM) [9]. Although this review hardly covers the entire wealth of scientific literature on the subject, we have attempted to revisit discoveries and philosophical concepts over the past 300 years to fit current work on cellular mechanics into an historical perspective. We hope such perspective will reveal that although we are asking similar questions as early scientists, modern nanoscale approaches are finally providing robust quantitative descriptions of cellular mechanics. These modern approaches are becoming of great importance as the role of nanoscience in physiology and medicine is now emerging.

The role of mechanical forces in biology is certainly not a new idea but is currently gaining wider acceptance. However, this has not always been the case. In 1850, Carpenter wrote "the degree to which the phenomena of Life are dependent upon Physical agencies has been the subject of inquiry and speculation among scientific investigators of almost every school. That many actions taking place in the living body are conformable to the laws of mechanics, has been hastily assumed as justifying the conclusion that all its actions are mechanical..." In 1917, Thompson discussed the apparent mechanical nature of cellular processes in his classic On Growth and Form [5], writing that “...though they resemble known physical phenomena, their nature is still the subject of much dubiety and discussion, and neither the forms produced nor the forces at work can yet be satisfactorily and simply explained." At about this time, many reports were emerging which began to quantify mechanical properties in cells which, until this point, had largely been supported by qualitative, empirical observations. Moreover, early debates about the appropriate theoretical picture one should have about the cell were also emerging $[3,4,10,11]$. Cells were initially thought to be of homogeneous gels, sols, viscoelastic and plastic fluids. These lines of thought continue today; however, many models have been developed which describe cellular mechanics in several ways, including a viscoelastic continuum, a combination of discrete mechanical elements, or a combination of viscoelastic fluid within a dense meshwork [6-8, 12-18]. However, for the number of models which exist today, there seem to be just as many experimental proofs which either support or refute each proposed model (for example, recent work on the soft glass rheology phenomenon $[19,20])$. Through experimental refinement over the past century, highly accurate measurements of viscosity, elasticity, plasticity and motion have been carried out by several techniques. However, this has not led to a complete theoretical description of cell mechanics that is both time-dependent and predictive.

Importantly, it is not fully understood whether these mechanical phenomena and properties are merely side products of biological processes or if they are intimately controlled at the genetic and physiological level through feedback loops, actuation and/or response pathways. In the past several years, some reports have begun to answer this highly complex question [21-25]. Here, we will generally limit our discussion towards AFM-based contributions, given the scope and contributors to this special issue on nanophysiology in the Pflügers Archiv European Journal of Physiology. However, contributions from many fields and techniques have been fundamental in the development of our current understanding of cellular mechanics [6-8]. Clearly, the field of cell mechanics and especially its relation to cell physiology or nanophysiology is vital and growing as many avenues exist to explore the micro- and nano-scopic cellular world. In this review, we will attempt to place modern AFM work side-by-side with studies from the seventeenth century onward to fit our understanding within a fascinating and sometimes surprising historical framework.

The architecture of the protoplasm In the late nineteenth century, cell doctrine was being generalized and the term protoplasm was used widely as a description of the contents of a cell [3, 26-30]. Early on, the protoplasm was viewed almost spiritually, as it had the ability to self-replicate, and many at the time accepted the idea of so-called vital and physical forces existing within the cell. Vitalists believed that vital forces emanated directly from the "Will of the Omnipotent and Ominpresent Creator" [31], and physical forces were a result or the modi operandi of Vital forces. Over time, there emerged a great debate between the "Vitalists" and "Mechanists" about the structure, function and purpose of the protoplasm, where mechanists believed that all processes within the cell could be explained by physical or chemical mechanics $[32,33]$. Many of these arguments actually continued well into the twentieth century, often arising from the inability of scientists to determine the exact chemical structure of the protoplasm or to explain certain mechanical phenomena [34-37].

The main elements of cellular architecture within the protoplasm were determined in the mid to late $1800 \mathrm{~s}$, and 
up until that point, cells were considered as small compartments containing homogeneous fluids [38]. With the development of modern microscopic techniques during the eighteenth and nineteenth centuries [1], including darkfield illumination, oil immersion lenses and high-quality glass optics free from aberrations, together with advances in sample preparation and staining methods (developed by the great European histologists such as Golgi, 1906 Nobel Laureate), the nucleus, nucleoli, chromatin, nuclear membranes, vacuoles, cytoplasmic streaming, filamentous structures (cytoskeleton, reticulum, the mitotic spindle, and actin-myosin striations in muscle) were observed [28-30, 38-40] (Fig. 1). The granular nature of the protoplasm led to the belief that it was accurately described as a colloidal suspension, giving rise to the early discussions and measurements of viscosity $[4,30]$. As with the development of the optical microscope, the AFM, a new paradigm in microscopy, was utilized early on to visualize some of these cellular structures.

Early AFM imaging of live cells quickly revealed the ability to image elements of the cytoskeleton as well as monitoring its dynamics [41-45]. Nuclei were often observed as large structures and contributing significantly to the apparent height of the cells. Due to the nature of AFM imaging, mechanical information was readily inferred and later quantified using various imaging mechanisms [41, 46, 47]. High-resolution AFM imaging has provided detailed information on the structure, function and mechanics of nucleic acids [48-55], several types of membrane proteins [56-61], nuclear pore complexes [62-67], biological filaments [68-77], molecular motors [78-83] and cell wall surfaces [84-92] which was not accessible with optical microscopy in the 1800s. Although there are many technological differences between both optical and scanning probe microscopy techniques, separated by well over a century, both have intriguingly pointed towards the mechanical nature of the cell.

Protoplasmic mechanics In a series of three lectures given by Stuart [93] in 1737 and 1738, it was shown that blood, blood vessels and nerves, dissected from a corpse, could all be tested mechanically. Early concepts of hydrostatics, elasticity and viscoelastic fluids were discussed and, apparently, it was observed that nerves were inelastic. In the living organism, mechanical oscillations were studied at length. In his lecture in 1857, Paget [94] discusses the spontaneous contractions of the heart after being removed from a living organism. The mechanical contractions were observed to continue without the need for a functioning nervous system, a property of heart and muscle cells which have been exploited recently in the AFM literature [95-98]. Other mechanical oscillations were discussed such as observations on $\sim 3 \mu \mathrm{m}$ diameter vacuoles in several organisms, cell-wall oscillations in plants and the movement of cilia [94]. In each of these cases, no known muscle structure or nervous system was present. It was not understood how such mechanical oscillations provided an advantage to these organisms. However, the concept of biological mechanics was clearly under development.

Early studies on the mechanical properties of the protoplasm were mainly concerned with viscosity. This was partly due to experimental limitations as microscopic methods of observation were not yet well developed (Fig. 2). Cytoplasmic streaming (the circular flow of cytoplasm in eukaryotic cells) was observed very early [4, 99] and used as a qualitative measure of the protoplasmic viscosity. It was also clear that the motion of internal
Fig. 1 Images of living cells from the late nineteenth century. a Detailed studies of mitosis were completed by Campbell in 1890 (image reproduced with permission from the Torrey Botanical Society [172]). b Striated structures were observed in cardiomyocytes of many species including humans in 1887 (image reproduced with permission from the American Society of Microscopists [173]). c Modern immunofluorescence staining of actin with rhodamine-phalloidin, over a century later, also reveals striated structures in rat cardiomyocytes a
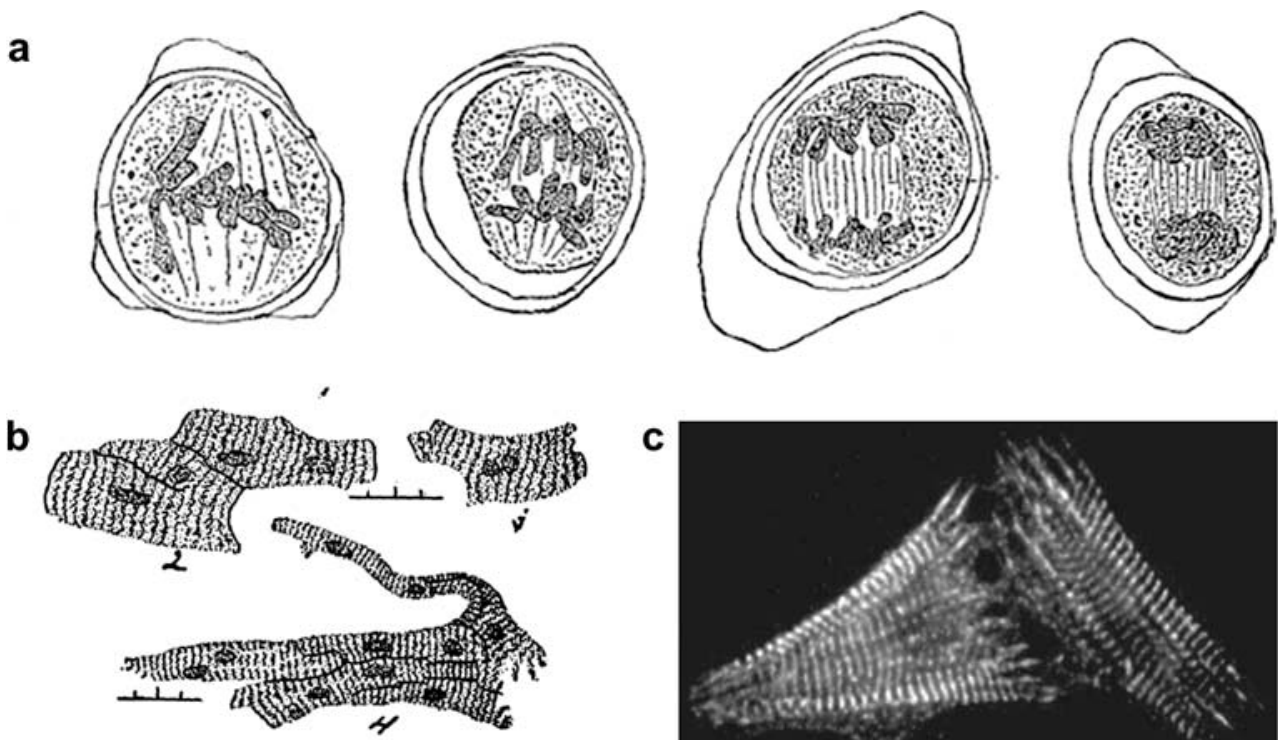

FIG. IV. MOUSE.

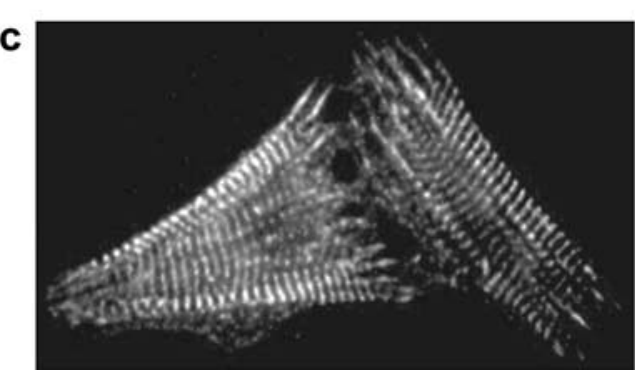


Fig. 2 Early microscopes used in the study of cellular mechanics. a The Leeuwenhoek microscope from the early 1600 s was one of the first utilized in early microscopy (image reproduced with permission from Molecular Expressions images). b The magnetic microscope from the 1920s used in studies which were the predecessors of modern particle microrheology. The microscope incorporated an electromagnet (arrow) into the design to oscillate magnetic microparticles inserted into living cells (image reproduced with permission from The Company of Biologists [103]). c The modern AFM, integrated with an inverted laser scanning confocal microscope to allow simultaneous mechanical perturbations and measurements to be performed while imaging cellular structures in three dimensions
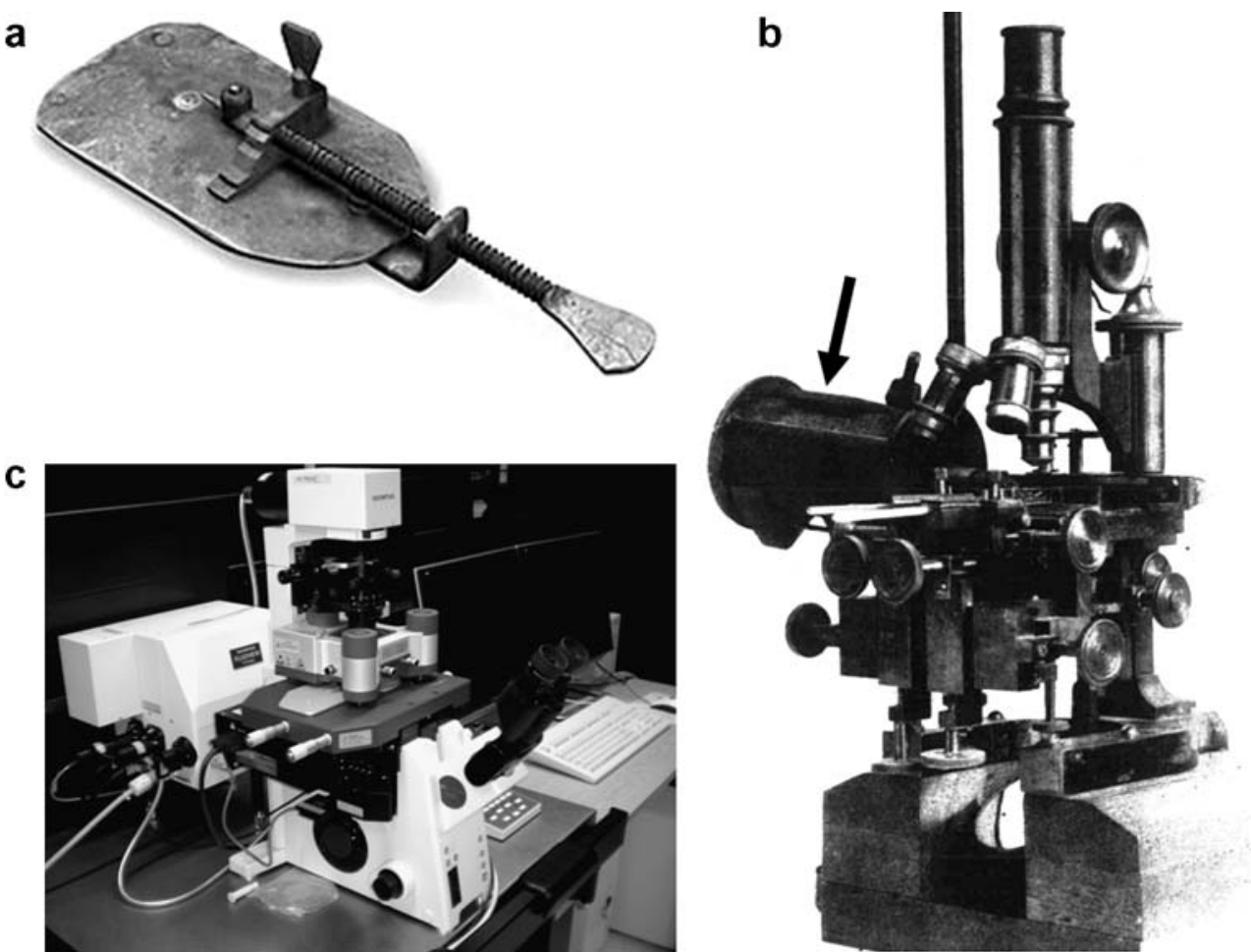

granules could also be used as markers for viscosity measurements [3, 4]. This represents some of the earliest uses of particle tracking in cell mechanics and is essentially a predecessor of modern-particle tracking and microrheology measurements [100, 101]. Although this early work was carried out in the 1920s and suffers from an obvious lack of appropriate experimental and theoretical considerations, some of the same issues were being discussed as they are today, such as the influence of the size of the granule, the mesh size of the protoplasm, damage to the cell and the influence of temperature $[3,4$, 102]. Similarly, an early magnetic microscope developed in 1923 [103] was used to oscillate nickel particles $(\sim 16 \mu \mathrm{m}$ in diameter) inserted into living cells. Aside from the similarities to modern particle micro-rheology [19, 20, $100,101]$, this approach is similar in concept to magnetic bead-twisting cytometry [104-106]. An early example of magnetic manipulation also involved injecting iron particles into bacteria and observing how fast they were attracted to an electromagnet [4]. A distinct but very common approach to viscosity measurements at the time involved the centrifugation of cells. Granules would be "thrown to one end of the cell" and slowly migrate back to their original position", a qualitative estimate of protoplasm viscosity at the time [4].

Changes in viscosity were measured during sea urchin egg mitosis and fertilization, sometimes by as much as two orders of magnitude [4]. Interestingly, it was also observed that preventing changes in viscosity could halt mitosis [107, 108]. Furthermore, changes in protoplasmic viscosity in response to the action of temperature, radiation, electric currents and several chemicals (anaesthetics, salt, organic solvents, and even the early chemotherapy agents being developed in the 1940s) have all been measured [3, 4, 29, 107, 109-124]. Although the major observable in AFM studies is the Young's modulus or elasticity (which is a related but fundamentally different parameter from viscosity), similar measurements have been performed in cells over the last two decades with AFM. These include the effects of anti-cytoskeletal drugs $[41,125,126]$, chemotherapy reagents [114, 127] and electrical stimulation [27, 128].

The majority of AFM mechanical measurements on living cells rely on nano-indentation approaches and extracting mechanical parameters from measured forcedisplacement curves. Although the main mechanical indicator is taken to be elasticity, rheological parameters have also been extracted from living cells using various approaches [129-131]. Indentation approaches have been used in conjunction with scanning to produce force maps [41-44, 132] or in single spots on living cells to measure time dependence $[125,127]$. Early indentation experiments on living cells almost a century ago employed the use of glass microneedles which were slowly inserted into many cell types to estimate viscosity [39, 133-135]. Although very qualitative, this method and variants of "microdissection" became a very common way to estimate the mechanical properties of the protoplasm. In 1931, a "microoperation" with a microneedle was described in which 
needles were used to push and penetrate into organelles of living cells [135]. Interestingly, in 2005, a "nanoscale operation" was described in which an AFM tip, modified with a nanoneedle, was employed to push and penetrate into the nucleus of living cells [136]. Although separated by about three quarters of a century, both reports describe the penetration and deformation of the cell nucleus using very similar approaches (Fig. 3). Granted, the AFM measurement provided a quantitative measure of force which was not possible with the early report. Furthermore, simultaneous laser scanning confocal imaging (Fig. 2) provides much more detailed three-dimensional information which was also not possible in 1931 .

Just prior to the development of the AFM in 1986, "cell poking" with calibrated microneedles was developed [137139]. Unlike the early methods which pushed the needle straight through the cell, the needle was indented into the cell membrane to measure cellular deformations and elasticity. Complementary to much older work from the late 1920s, the effect of anti-cytoskeletal drugs were also measured [137]. Some early examples of whole-cell elasticity were demonstrated using plant cells [140]. Plant tissue was clamped on either end and stretched using

a

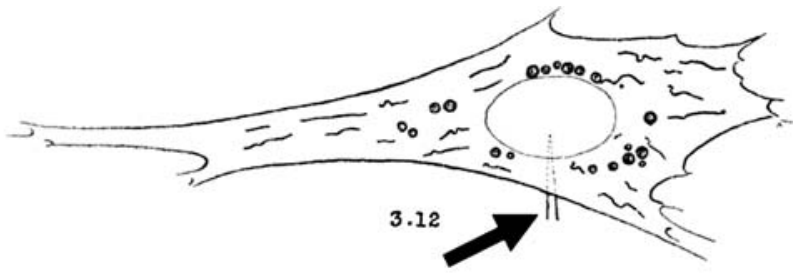

b

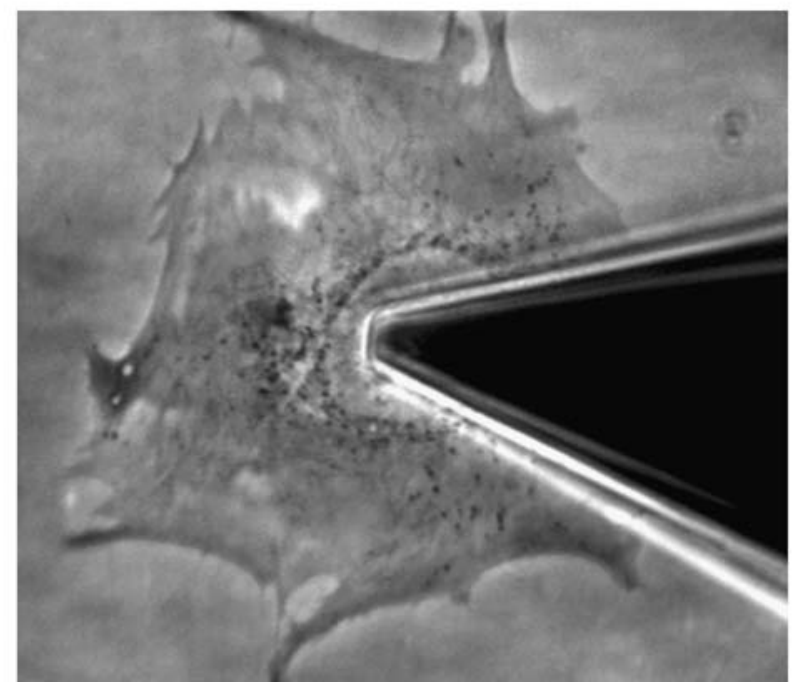

Fig. 3 Cell indentation as a means of measuring mechanical properties was developed as in the early 1900s. a In 1931, glass microneedles (arrow) were used to "operate" on living cells by indenting and eventually entering the nucleus (image reproduced with permission from the Royal Society [135]). b Much later, modern techniques using AFM as seen in the phase-contrast micrograph. These similar methods of "nano-indentation" have also been described as "nano-operations" [136] known weights to produce stress-strain curves. Conceptually, this work is related to modern directions towards investigating multi-cellular assemblies, monolayers and tissues $[16,24,25,141]$. Micropipette aspiration [142145] has also come into use to study whole-cell mechanics by examining cellular and nuclear deformations in response to suction [146-149]. Microplates [150, 151] have been employed to measure cellular deformation and elasticity in response to force. Cells have been either literally "ploughed" from a surface using a cantilever to measure adhesion forces which aid in attachment and motility [152]. There is an extensive literature, dating back to the late $1800 \mathrm{~s}$, on wound healing and migration which are also highly mechanical in nature [153]. Recently, AFM has been used to measure the protrusive forces $[44,154]$ at the edge of migrating cells in complement to traction force assays [155, 156], micropipette and laser trap studies [157]. Migration is a key element in cancer metastasis, and in recent years, cells have been optically trapped and stretched in electromagnetic fields to measure mechanical properties in relation to metastatic potential [158-161] (complementary to early deformability assays [162]). In addition, magnetic traps have been utilized to perform rheological measurements with magnetic beads [20, 163-165]. Measurements of mechanical parameters, organelle deformations and force transmission have all been performed with magnetic bead-twisting cytometry $[163,166]$. These studies are similar in concept to the early studies by Seifriz [103] and his magnetic microscope as well as early organelle tracking in response to indentations with micropipettes [135].

Obviously, there have been a wide variety of approaches demonstrated over the past 150 years to measure the mechanical properties of living cells. Although the mechanical properties of living cells and organisms was initially very conceptual, we have witnessed a significant growth in the methodologies employed to measure such properties [6-8]. Many laboratories worldwide have become expert at measuring mechanical properties of cells; however, it is clear from the above literature review that many of the same questions are being asked today that were posed and explored over the past century. Clearly, biological cells and tissues possess mechanical properties, and these properties do appear to change during physiological processes and in disease. Mechanical detection of these states may indeed be a key development important for the future of 'nanomedicine' and 'nanophysiology'. However, these concepts have existed for some time, and it begs the question-Is there more we can do aside from developing very accurate tools to mechanically detect biological processes?

Outlook on cell mechanics and "nanophysiology" In 1737, Stuart [93] originally discussed the idea of being able to 
control the heart by stimulating it correctly. Although the measurement of accurate mechanical parameters is of extreme importance, the idea of controlling and altering biological pathways is equally enticing. Previously, it has been shown that mechanical force delivered by the AFM tip can induce various chemo-mechanical responses [167169]. In recent work, it has also been shown that the mechanical environment of many cell types (including cancer and stem cells) can be used to control and alter gene expression and differentiation pathways $[21-25,164,170$, 171]. We now have the tools to measure mechanical properties, and we have the tools to alter the mechanical environment of a cell or even deliver well-defined forces to a cell. Therefore, can we now move towards initiating and controlling biological pathways in cell cultures and perhaps, one day, in vivo? Perhaps, the emerging field of nanophysiology will include a branch dedicated to the nanomechanical control of biological pathways. This poorly understood area of pursuit, in concert with ultrasensitive detection technologies and modern pharmaceutical treatments, may have a significant role to play in the development of nanomedicine and the diagnosis and treatment of diseases.

Complementary to the many applications one may envision for nanotechnology in medicine and physiology, it is also becoming clear that the governing physical principles of cell mechanics remain poorly understood and the subject of intense debate. Specifically, the concept of elasticity is ill-defined for a living cell. The cell is heterogeneous, dynamic, undergoes continuous cytoskeletal remodelling and likely highly anisotropic. Therefore, the Hertz model, commonly used in AFM nanoindentation experiments, does not ideally apply. Furthermore, the cellular Poisson ratio is equally ill-defined and has conventionally been taken to be constant, although this may not actually be the case. There is no evidence to show that the Poisson ratio does not itself change during physiological processes, and this may or may not be correlated to changes in Young's modulus. Therefore, as mentioned above, our theoretical descriptions of cell mechanics still require much further development. However, there is no doubt this will occur as future debates and empirical observations take place.

Conclusions regarding cellular mechanics are often drawn from studies carried out on one cell type, under a limited set of conditions, and generalized towards a broad range of cells, if not all cells. However, we suggest that mechanical responses and the biochemical/structural basis for mechanical parameters are likely dependent on the type, physiological and mechanical environment of the cell. Although many cell types contain the same structural components (that is, the cytoplasm, cytoskeleton, nucleus, membranes, etc.), it may be unlikely to utilize them along identical pathways during biological processes. Therefore, rather than searching for a unified theory of cell mechanics, we, as a community, might try to identify heterogeneity in phenotypic mechanical responses and transduction pathways in living cells. Classification might be according to the mechanical model(s) (or combination of models) which describes the cell most appropriately, along the lines of which signalling pathway(s) are activated upon mechanical stimulation, which internal structures are important for mechanotransduction, or the mechanical changes which take place during physiological processes.

Regardless of this speculation, the field of cell mechanics is alive and well. The trend towards interdisciplinary research among so-called nanoscientists is an encouraging one and represents one of the major advances in the field of cell mechanics. In the early studies of the protoplasm, there was significant antagonism and territorial fighting between biologists and chemists [37]. Today, we see that scientists are becoming ever more able and willing to cross diverse disciplinary lines. As we look back on the history of cell mechanics, we realize that it was only about 100 years ago that a raging debate was taking place about the components of the protoplasm. Certainly, the field today is full of speculation, inconsistencies and disagreement, but this is what drives science forward.

Acknowledgements We gratefully acknowledge the 'Dr. Mortimer and Mrs. Theresa Sackler Trust' and the Wellcome Trust for funding this work.

\section{References}

1. Seifriz W (1937) Methods of research on the physical properties of the protoplasm. Plant Physiol 12:99-116

2. Egerton F (2006) A history of the ecological sciences, Part 19. Leeuwenhoek. Bull Ecol Soc Am 87:47-58

3. Heilbrunn LV (1926) The physical structure of the protoplasm of sea-urchin eggs. Am Nat 60:143-156

4. Heilbrunn LV (1927) The viscosity of the protoplasm. Q Rev Biol 2:230-248

5. Thompson DAW (1917) On growth and form, 1st edn. Cambridge University Press, Cambridge, England

6. Wang Y-1, Discher DE (2007) Cell mechanics, 1st edn. Elsevier Academic, Amsterdam

7. Boal DH (2002) Mechanics of the cell, 2nd edn. Cambridge University Press, Cambridge, UK

8. Mofrad MRK, Kamm RD (2006) Cytoskeletal mechanics: models and measurements, 1st edn. Cambridge University Press, Cambridge

9. Binnig G, Quate CF, Gerber C (1986) Atomic force microscope. Phys Rev Lett 56:930-933

10. Bingham EC (1933) Fluidity and plasticity, 1st edn. McGrawHill, New York

11. Heilbrunn LV (1924) The surface tension theory of membrane elevation. Bio Bull 46:277-280

12. Bao G, Suresh S (2003) Cell and molecular mechanics of biological materials. Nat Mater 2:715-725 
13. Charras GT, Yarrow JC, Horton MA, Mahadevan L, Mitchison TJ (2005) Non-equilibration of hydrostatic pressure in blebbing cells. Nature 435:365-369

14. Dai J, Sheetz MP (1998) Cell membrane mechanics. Methods Cell Biol 55:157-171

15. Heidemann SR, Lamoureaux P, Buxbaum RE (2000) Opposing views on tensegrity as a structural framework for understanding cell mechanics. J Appl Physiol 89:1670-1678

16. Huang H, Kamm RD, Lee RT (2004) Cell mechanics and mechanotransduction: pathways, probes, and physiology. Am J Physiol Cell Physiol 287:C1-C11

17. Ingber DE (2000) Opposing views on tensegrity as a structural framework for understanding cell mechanics. J Appl Physiol 89:1663-1670

18. Kasza KE, Rowat AC, Liu J, Angelini TE, Brangwynne CP, Koenderink GH, Weitz DA (2007) The cell as a material. Curr Opin Cell Biol 19:101-107

19. Trepat X, Deng L, An SS, Navajas D, Tschumperlin DJ, Gerthoffer WT, Butler JP, Fredberg JJ (2007) Universal physical responses to stretch in the living cell. Nature 447:592-595

20. Stamenovic D, Rosenblatt N, Montoya-Zavala M, Matthews BD, Hu S, Suki B, Wang N, Ingber DE (2007) Rheological behavior of living cells is timescale-dependent. Biophys. J. 93:L39-L41

21. Even-Ram S, Artym V, Yamada KM (2006) Matrix control of stem cell fate. Cell 126:645-647

22. Engler AJ, Sen S, Sweeney HL, Discher DE (2006) Matrix elasticity directs stem cell lineage specification. Cell 126:677689

23. Paszek MJ, Zahir N, Johnson KR, Lakins JN, Rozenberg GI, Gefen A, Reinhart-King CA, Margulies SS, Dembo M, Boettiger D, Hammer DA, Weaver VM (2005) Tensional homeostasis and the malignant phenotype. Cancer Cell 8:241-254

24. Ingber DE (2006) Mechanical control of tissue morphogenesis during embryological development. Int J Dev Biol 50:255-266

25. Ingber DE (2005) Mechanical control of tissue growth: function follows form. Proc Natl Acad Sci USA 102:11571-11572

26. Harper RA (1919) The Structure of Protoplasm. Am J Bot 6:273-300

27. Greely AW (1904) Experiments on the physical stucture of the protoplasm of paramœcium and its relation to the reactions of the organism to thermal, chemical and electrical stimuli. Bio Bull $7: 3-32$

28. Goodale GL (1889) Protoplasm and its history. Bot Gaz 14:235-246

29. Seifriz W (1931) The structure of protoplasm. Science 1902:648-649

30. Wilson EB (1899) The structure of the protoplasm. Science 237:33-45

31. Carpenter WB (1850) On the mutual relations of the vital and physical forces. Philos Trans Roy Soc Lond 140:727-757

32. Osterhout WJV (1914) The chemical dynamics of living protoplasm. Science 39:544-546

33. Seifriz W (1939) A materialistic interpretation of life. Phil Sci 6:266-284

34. Myers CS (1900) Vitalism: a brief historical and critical review. Mind 9:319-331

35. Grossman EF (1930) Something about vitalism and mechanism. Sci Mon 30:541-546

36. Sinnott EW (1956) Biology and spiritual values. J Religion $36: 177-189$

37. Geison GL (1969) The photoplasmic theory of life and the vitalist-mechanist debate. Isis 60:272-292

38. General Notes (1885) Physiology. Am Nat 19:1236-1241

39. Seifriz W (1918) Observations on the structure of protoplasm by aid of microdissection. Biol Bull 34:307-324

40. Lepeschkin WW (1928) The chemical and physical composition of the protoplasm. Science 1928:45-48
41. Rotsch C, Radmacher M (2000) Drug-induced changes of cytoskeletal structure and mechanics in fibroblasts: an atomic force microscopy study. Biophys J 78:520-535

42. Rotsch C, Jacobson K, Radmacher M (1999) Dimensional and mechanical dynamics of active and stable edges in motile fibroblasts investigated by using atomic force microscopy. Proc Natl Acad Sci USA 96:921-926

43. Rotsch C, Braet F, Wisse E, Radmacher M (1997) AFM imaging and elasticity measurements on living rat liver macrophages. Cell Biol Int 21:685-696

44. Radmacher M (2007) Studying the mechanics of cellular processes by atomic force microscopy. Methods Cell Biol 83:347-372

45. Pesen D, Hoh JH (2005) Micromechanical architecture of the endothelial cell cortex. Biophys J 88:670-679

46. Haga H, Nagayama M, Kawabata K, Ito E, Ushiki T, Sambongi $\mathrm{T}$ (2000) Time-lapse viscoelastic imaging of living fibroblasts using force modulation mode in AFM. J Electron Microsc (Tokyo) 49:473-481

47. Nagao E, Dvorak JA (1998) An integrated approach to the study of living cells by atomic force microscopy. J Microsc 191:8-19

48. Sattin BD, Pelling AE, Goh MC (2004) DNA base pair resolution by single molecule force spectroscopy. Nucleic Acids Res 32:4876-4883

49. Sattin BD, Goh MC (2004) Direct observation of the assembly of RecA/DNA complexes by atomic force microscopy. Biophys J 87:3430-3436

50. Hansma HG (2001) Surface biology of DNA by atomic force microscopy. Annu Rev Phys Chem 52:71-92

51. Hansma HG, Laney DE, Bezanilla M, Sinsheimer RL, Hansma PK (1995) Applications for atomic force microscopy of DNA. Biophys J 68:1672-1677

52. Hansma HG, Sinsheimer RL, Li MQ, Hansma PK (1992) Atomic force microscopy of single- and double-stranded DNA. Nucleic Acids Res 20:3585-3590

53. Hansma HG, Vesenka J, Siegerist C, Kelderman G, Morrett H, Sinsheimer RL, Elings V, Bustamante C, Hansma PK (1992) Reproducible imaging and dissection of plasmid DNA under liquid with the atomic force microscope. Science 256:1180-1184

54. Lindsay SM, Nagahara LA, Thundat T, Knipping U, Rill RL, Drake B, Prater CB, Weisenhorn AL, Gould SA, Hansma PK (1989) STM and AFM images of nucleosome DNA under water. J Biomol Struct Dyn 7:279-287

55. Weisenhorn AL, Gaub HE, Hansma HG, Sinsheimer RL, Kelderman GL, Hansma PK (1990) Imaging single-stranded DNA, antigen-antibody reaction and polymerized LangmuirBlodgett films with an atomic force microscope. Scanning Microsc 4:511-516

56. Scheuring S, Sturgis JN, Prima V, Bernadac A, Levy D, Rigaud JL (2004) Watching the photosynthetic apparatus in native membranes. Proc Natl Acad Sci USA 101:11293-11297

57. Muller DJ, Sapra KT, Scheuring S, Kedrov A, Frederix PL, Fotiadis D, Engel A (2006) Single-molecule studies of membrane proteins. Curr Opin Struct Biol 16:489-495

58. Scheuring S (2006) AFM studies of the supramolecular assembly of bacterial photosynthetic core-complexes. Curr Opin Chem Biol 10:387-393

59. Buzhynskyy N, Hite RK, Walz T, Scheuring S (2007) The supramolecular architecture of junctional microdomains in native lens membranes. EMBO Rep 8:51-55

60. Horton M, Charras G, Lehenkari P (2002) Analysis of ligandreceptor interactions in cells by atomic force microscopy. J Recept Signal Transduct Res 22:169-190

61. Lehenkari PP, Horton MA (1999) Single integrin molecule adhesion forces in intact cells measured by atomic force microscopy. Biochem Biophys Res Commun 259:645-650 
62. Maco B, Fahrenkrog B, Huang NP, Aebi U (2006) Nuclear pore complex structure and plasticity revealed by electron and atomic force microscopy. Methods Mol Biol 322:273-288

63. Mooren OL, Erickson ES, Moore-Nichols D, Dunn RC (2004) Nuclear side conformational changes in the nuclear pore complex following calcium release from the nuclear membrane. Phys Biol 1:125-134

64. Erickson ES, Mooren OL, Moore-Nichols D, Dunn RC (2004) Activation of ryanodine receptors in the nuclear envelope alters the conformation of the nuclear pore complex. Biophys Chem 112:1-7

65. Wang H, Clapham DE (1999) Conformational changes of the in situ nuclear pore complex. Biophys J 77:241-247

66. Schneider S, Folprecht G, Krohne G, Oberleithner H (1995) Immunolocalization of lamins and nuclear pore complex proteins by atomic force microscopy. Pflugers Arch 430:795-801

67. Bustamante JO, Liepins A, Prendergast RA, Hanover JA, Oberleithner H (1995) Patch clamp and atomic force microscopy demonstrate TATA-binding protein (TBP) interactions with the nuclear pore complex. J Membr Biol 146:263-272

68. Friedrichs J, Taubenberger A, Franz CM, Muller DJ (2007) Cellular remodelling of individual collagen fibrils visualized by time-lapse AFM. J Mol Biol 372:594-607

69. Kasas S, Wang X, Hirling H, Marsault R, Huni B, Yersin A, Regazzi R, Grenningloh G, Riederer B, Forro L, Dietler G, Catsicas S (2005) Superficial and deep changes of cellular mechanical properties following cytoskeleton disassembly. Cell Motil Cytoskelet 62:124-132

70. Lehto T, Miaczynska M, Zerial M, Muller DJ, Severin F (2003) Observing the growth of individual actin filaments in cell extracts by time-lapse atomic force microscopy. FEBS Lett 551:25-28

71. Paige MF, Rainey JK, Goh MC (2001) A study of fibrous long spacing collagen ultrastructure and assembly by atomic force microscopy. Micron 32:341-353

72. Parekh SH, Chaudhuri O, Theriot JA, Fletcher DA (2005) Loading history determines the velocity of actin-network growth. Nat Cell Biol 7:1219-1223

73. Shao Z, Shi D, Somlyo AV (2000) Cryoatomic force microscopy of filamentous actin. Biophys J 78:950-958

74. Smith JF, Knowles TP, Dobson CM, Macphee CE, Welland ME (2006) Characterization of the nanoscale properties of individual amyloid fibrils. Proc Natl Acad Sci USA 103:15806-15811

75. Thomson NH, Kasas S, Riederer BM, Catsicas S, Dietler G, Kulik AJ, Forro L (2003) Large fluctuations in the disassembly rate of microtubules revealed by atomic force microscopy. Ultramicroscopy 97:239-247

76. Wenger MP, Bozec L, Horton MA, Mesquida P (2007) Mechanical properties of collagen fibrils. Biophys J 93:12551263

77. Wen CK, Goh MC (2004) AFM nanodissection reveals internal structural details of single collagen fibrils. Nano Lett 4:129-132

78. Taniguchi M, Matsumoto O, Suzuki S, Nishino Y, Okuda A, Taga T, Yamane T (2003) MgATP-induced conformational changes in a single myosin molecule observed by atomic force microscopy: periodicity of substructures in myosin rods. Scanning 25:223-229

79. Kodera N, Kinoshita T, Ito T, Ando T (2003) High-resolution imaging of myosin motor in action by a high-speed atomic force microscope. Adv Exp Med Biol 538:119-127

80. Yamada T, Kunioka Y, Wakayama J, Aimi M, Noguchi YS, Akiyama N, Kayamori T (2003) Molecular organizations of myofibrils of skeletal muscle studied by atomic force microscopy. Adv Exp Med Biol 538:285-294, (discussion 294)

81. Ando T, Kodera N, Takai E, Maruyama D, Saito K, Toda A (2001) A high-speed atomic force microscope for studying biological macromolecules. Proc Natl Acad Sci USA 98: 12468-12472

82. Hallett P, Offer G, Miles MJ (1995) Atomic force microscopy of the myosin molecule. Biophys J 68:1604-1606

83. Sheng S, Gao Y, Khromov AS, Somlyo AV, Somlyo AP, Shao Z (2003) Cryo-atomic force microscopy of unphosphorylated and thiophosphorylated single smooth muscle myosin molecules. J Biol Chem 278:39892-39896

84. Pelling AE, Li Y, Cross SE, Castaneda S, Shi W, Gimzewski JK (2006) Self-organized and highly ordered domain structures within swarms of Myxococcus xanthus. Cell Motil Cytoskeleton 63:141-148

85. Pelling AE, Li Y, Shi W, Gimzewski JK (2005) Nanoscale visualization and characterization of Myxococcus xanthus cells with atomic force microscopy. Proc Natl Acad Sci USA 102:6484-6489

86. Pelling AE, Sehati S, Gralla EB, Valentine JS, Gimzewski JK (2004) Local nanomechanical motion of the cell wall of Saccharomyces cerevisiae. Science 305:1147-1150

87. Ahimou F, Touhami A, Dufrene YF (2003) Real-time imaging of the surface topography of living yeast cells by atomic force microscopy. Yeast 20:25-30

88. Dague E, Alsteens D, Latge JP, Dufrene Y (2007) Highresolution cell surface dynamics of germinating FS. Biophys J

89. Gaboriaud F, Dufrene YF (2007) Atomic force microscopy of microbial cells: application to nanomechanical properties, surface forces and molecular recognition forces. Colloids Surf B Biointerfaces 54:10-19

90. Touhami A, Jericho MH, Beveridge TJ (2004) Atomic force microscopy of cell growth and division in Staphylococcus aureus. J Bacteriol 186:3286-3295

91. Cross SE, Kreth J, Zhu L, Sullivan R, Shi W, Qi F, Gimzewski JK (2007) Nanomechanical properties of glucans and associated cell-surface adhesion of Streptococcus mutans probed by atomic force microscopy under in situ conditions. Microbiology $153: 3124-3132$

92. Hinterdorfer P, Dufrene YF (2006) Detection and localization of single molecular recognition events using atomic force microscopy. Nat Methods 3:347-355

93. Stuart A (1738) Three lectures on muscular motion, read before the Royal Society in the Year MDCCXXXVIII: As appointed by the will of Lady Sadleir, pursuant to the design of her first husband William Croone, M. D. Fellow of the College of Physicians, and of the Royal Society: being a supplement to the philosophical transactions for that year. Wherein the elasticity of fluids, and the immediate cause of the cohesion and elasticity of solids, are proved by experiments, \&c. and shewn to arise from the same principle as gravity: with a general scheme of muscular motion, founded on anatomy, experiments, etc. Phil Trans (1638-1775) 40:i-liv

94. Paget J (1857) Croonian lecture: on the cause of the rhythmic motion of the heart. Proc Roy Soc London 8:473-488

95. Domke J, Parak WJ, George M, Gaub HE, Radmacher M (1999) Mapping the mechanical pulse of single cardiomyocytes with the atomic force microscope. Eur Biophys J Biophy 28:179-186

96. Shroff SG, Saner DR, Lal R (1995) Dynamic micromechanical properties of cultured rat atrial myocytes measured by atomic force microscopy. Am J Physiol 269:C286-C292

97. Pelling AE, Veraitch FS, Pui-Kei Chu C, Nicholls BM, Hemsley AL, Mason C, Horton MA (2007) Mapping correlated membrane pulsations and fluctuations in human cells. J Mol Recognit (in press)

98. Haupt BJ, Pelling AE, Horton MA (2006) Integrated confocal and scanning probe microscopy for biomedical research. Sci World J 6:1609-1618

99. Ewart AJ (1901) On the physics and physiology of the protoplasmic streaming in plants. Proc Roy Soc London 69:466-470 
100. Weihs D, Mason TG, Teitell MA (2006) Bio-microrheology: a frontier in microrheology. Biophys J 91:4296-4305

101. Mason TG, Ganesan K, vanZanten JH, Wirtz D, Kuo SC (1997) Particle tracking microrheology of complex fluids. Phys Rev Lett 79:3282-3285

102. Valentine MT, Perlman ZE, Gardel ML, Shin JH, Matsudaira P, Mitchison TJ, Weitz DA (2004) Colloid surface chemistry critically affects multiple particle tracking measurements of biomaterials. Biophys J 86:4004-4014

103. Seifriz W (1924) An elastic value of protoplasm, with further observations on the viscosity of protoplasm. J Exp Biol 2:1-11

104. Valberg PA, Albertini DF (1985) Cytoplasmic motions, rheology, and structure probed by a novel magnetic particle method. J Cell Biol 101:130-140

105. Lele TP, Sero JE, Matthews BD, Kumar S, Xia S, MontoyaZavala M, Polte T, Overby D, Wang N, Ingber DE (2007) Tools to study cell mechanics and mechanotransduction. Methods Cell Biol 83:443-472

106. Massiera G, Van Citters KM, Biancaniello PL, Crocker JC (2007) Mechanics of single cells: rheology, time dependence and fluctuations. Biophys J 93:3703-3713

107. Heilbrunn LV (1920) The physical effect of anesthetics upon living protoplasm. Bio Bull 39:307-315

108. Heilbrunn LV (1920) An experimental study of cell division. I. The physical conditions which determine the appearance of the spindle in sea-urchin eggs. J Exp Zool 30:211-237

109. Heilbrunn LV (1925) The electrical charges of living cells. Science 1574:236-237

110. Heilbrunn LV (1925) The action of ether on protoplasm. Bio Bull 49:461-476

111. Heilbrunn LV, Wilson WL (1948) Protoplasmic viscosity changes during mitosis in the egg of Chaetopterus. Bio Bull 95:57-68

112. Heilbrunn LV, Chaet AB, Dunn A, Wilson WL (1954) Antimitotic substances from ovaries. Bio Bull 106:158-168

113. Heilbrunn LV, Wilson WL, Tosteson TR, Davidson E, Rutman RJ (1957) The antimitotic and carcinostatic action of ovarian extracts. Bio Bull 113:129-134

114. Heilbrunn LV, Wilson WL (1957) A rational approach to the problem of cancer chemotherapy. Bio Bull 113:388-396

115. Seifriz W, Uraguchi M (1941) The toxic effects of heavy metals on protoplasm. Am J Bot 28:191-197

116. Scarth GW (1924) Colloidal changes associated with protoplasmic contraction. Q J Exp Physiol 14:99-113

117. Packard C (1931) The biological effects of short radiations. Q Rev Biol 6:253-280

118. Lepeschkin WW (1932) The influence of narcotics, mechanical agents, and light upon the permeability of protoplasm. Am J Bot 19:568-580

119. Jacobs MH (1922) The effect of carbon dioxide on the consistency of protoplasm. Bio Bull 42:14-30

120. Forbes A, Thacher C (1925) Changes in the protoplasm of Nereis eggs induced by ß-radiation. Am J Physiol 74:567-578

121. Carlson JG (1946) Protoplasmic viscosity changes in different regions of the grasshopper neuroblast during mitosis. Bio Bull 90:109-121

122. Bayliss WM (1920) The properties of colloidal systems. IV. Reversible gelation in living protoplasm. Proc Roy Soc London B 91:196-201

123. Angerer CA (1939) The effect of electric current on the relative viscosity of sea-urchin egg protoplasm. Bio Bull 77:399-406

124. Addoms RM (1927) Toxicity as evidenced by changes in the protoplasmic structure of root hairs of wheat. Am J Bot 14: 147-165

125. Pelling AE, Dawson DW, Carreon DM, Christiansen JJ, Shen RR, Teitell MA, Gimzewski JK (2007) Distinct contributions of microtubule subtypes to cell membrane shape and stability. Nanomedicine 3:43-52

126. Northern HT (1950) Alterations in the structural viscosity of protoplasm by colchicine and their relationship to C-mitosis and C-tumor formation. Am J Bot 37:705-711

127. Lam WA, Rosenbluth MJ, Fletcher DA (2007) Chemotherapy exposure increases leukemia cell stiffness. Blood 109:3505-3508

128. Zhang PC, Keleshian AM, Sachs F (2001) Voltage-induced membrane movement. Nature 413:428-432

129. Alcaraz J, Buscemi L, Grabulosa M, Trepat X, Fabry B, Farre R, Navajas D (2003) Microrheology of human lung epithelial cells measured by atomic force microscopy. Biophys J 84:2071-2079

130. Smith BA, Roy H, De Koninck P, Grutter P, De Koninck Y (2007) Dendritic spine viscoelasticity and soft-glassy nature: balancing dynamic remodeling with structural stability. Biophys J 92:1419-1430

131. Smith BA, Tolloczko B, Martin JG, Grutter P (2005) Probing the viscoelastic behavior of cultured airway smooth muscle cells with atomic force microscopy: stiffening induced by contractile agonist. Biophys J 88:2994-3007

132. Radmacher M (2002) Measuring the elastic properties of living cells by the atomic force microscope. Methods Cell Biol 68:67-90

133. Kite GL (1913) Studies on the physical properties of protoplasm. Am J Physiol 32:146-164

134. Chambers R (1915) Microdissection studies on the germ cell. Science 41:290-293

135. Chambers R, Fell HB (1931) Micro-operations on cells in tissue cultures. Proc Roy Soc London B 109:380-403

136. Obataya I, Nakamura C, Han S, Nakamura N, Miyake J (2005) Nanoscale operation of a living cell using an atomic force microscope with a nanoneedle. Nano Lett 5:27-30

137. Petersen NO, McConnaughey WB, Elson EL (1982) Dependence of locally measured cellular deformability on position on the cell, temperature, and cytochalasin B. Proc Natl Acad Sci USA 79:5327-5331

138. McConnaughey WB, Petersen NO (1980) Cell poker: an apparatus for stress-strain measurements on living cells. Rev Sci Instrum 51:575-580

139. Daily B, Elson EL, Zahalak GI (1984) Cell poking. Determination of the elastic area compressibility modulus of the erythrocyte membrane. Biophys J 45:671-682

140. Treitel O (1944) Elasticity of plant tissues. Trans Kans Acad Sci 47:219-239

141. Bray D (1984) Axonal growth in response to experimentally applied mechanical tension. Dev Biol 102:379-389

142. Waugh R, Evans EA (1979) Thermoelasticity of red blood cell membrane. Biophys J 26:115-131

143. Evans EA, Hochmuth RM (1976) Membrane viscoelasticity. Biophys J 16:1-11

144. Evans E, Yeung A (1989) Apparent viscosity and cortical tension of blood granulocytes determined by micropipet aspiration. Biophys J 56:151-160

145. Hochmuth RM (2000) Micropipette aspiration of living cells. J Biomech 33:15-22

146. Lammerding J, Schulze PC, Takahashi T, Kozlov S, Sullivan T, Kamm RD, Stewart CL, Lee RT (2004) Lamin A/C deficiency causes defective nuclear mechanics and mechanotransduction. J Clin Invest 113:370-378

147. Lammerding J, Fong LG, Ji JY, Reue K, Stewart CL, Young SG, Lee RT (2006) Lamins A and C but not lamin B1 regulate nuclear mechanics. J Biol Chem 281:25768-25780

148. Lammerding J, Dahl KN, Discher DE, Kamm RD (2007) Nuclear mechanics and methods. Methods Cell Biol 83:269-294

149. Rowat AC, Lammerding J, Ipsen JH (2006) Mechanical properties of the cell nucleus and the effect of emerin deficiency. Biophys J 91:4649-4664 
150. Thoumine O, Ott A, Cardoso O, Meister JJ (1999) Microplates: a new tool for manipulation and mechanical perturbation of individual cells. J Biochem Biophys Methods 39:47-62

151. Smith AE, Zhang Z, Thomas CR, Moxham KE, Middelberg AP (2000) The mechanical properties of $f s$. Proc Natl Acad Sci USA 97:9871-9874

152. Sagvolden G, Giaever I, Pettersen EO, Feder J (1999) Cell adhesion force microscopy. Proc Natl Acad Sci USA 96: 471-476

153. Herrick EH (1932) Mechanism of movement of epidermis, especially its melanophores, in wound healing, and behavior of skin grafts in frog tadpoles. Bio Bull 63:271-286

154. Prass M, Jacobson K, Mogilner A, Radmacher M (2006) Direct measurement of the lamellipodial protrusive force in a migrating cell. J Cell Biol 174:767-772

155. Pelham RJ Jr., Wang Y (1999) High resolution detection of mechanical forces exerted by locomoting fibroblasts on the substrate. Mol Biol Cell 10:935-945

156. Jurado C, Haserick JR, Lee J (2005) Slipping or gripping? Fluorescent speckle microscopy in fish keratocytes reveals two different mechanisms for generating a retrograde flow of actin. Mol Biol Cell 16:507-518

157. Li S, Guan JL, Chien S (2005) Biochemistry and biomechanics of cell motility. Annu Rev Biomed Eng 7:105-150

158. Svoboda K, Block SM (1994) Biological applications of optical forces. Annu Rev Biophys Biomol Struct 23:247-285

159. Svoboda K, Schmidt CF, Branton D, Block SM (1992) Conformation and elasticity of the isolated red blood cell membrane skeleton. Biophys J 63:784-793

160. Guck J, Ananthakrishnan R, Mahmood H, Moon TJ, Cunningham CC, Kas J (2001) The optical stretcher: a novel laser tool to micromanipulate cells. Biophys J 81:767-784

161. Guck J, Schinkinger S, Lincoln B, Wottawah F, Ebert S, Romeyke M, Lenz D, Erickson HM, Ananthakrishnan R, Mitchell D, Kas J, Ulvick S, Bilby C (2005) Optical deformability as an inherent cell marker for testing malignant transformation and metastatic competence. Biophys $\mathrm{J} 88$ : $3689-3698$
162. Ochalek T, Nordt FJ, Tullberg K, Burger MM (1988) Correlation between cell deformability and metastatic potential in B16-F1 melanoma cell variants. Cancer Res 48:5124-5128

163. Wang N, Butler JP, Ingber DE (1993) Mechanotransduction across the cell surface and through the cytoskeleton. Science 260:1124-1127

164. Wang N, Ingber DE (1994) Control of cytoskeletal mechanics by extracellular matrix, cell shape, and mechanical tension. Biophys J 66:2181-2189

165. Puig-De-Morales M, Grabulosa M, Alcaraz J, Mullol J, Maksym GN, Fredberg JJ, Navajas D (2001) Measurement of cell microrheology by magnetic twisting cytometry with frequency domain demodulation. J Appl Physiol 91:1152-1159

166. Hu S, Eberhard L, Chen J, Love JC, Butler JP, Fredberg JJ, Whitesides GM, Wang N (2004) Mechanical anisotropy of adherent cells probed by a three-dimensional magnetic twisting device. Am J Physiol Cell Physiol 287:C1184-1191

167. Charras GT, Horton MA (2002) Single cell mechanotransduction and its modulation analyzed by atomic force microscope indentation. Biophys J 82:2970-2981

168. Charras GT, Lehenkari PP, Horton MA (2001) Atomic force microscopy can be used to mechanically stimulate osteoblasts and evaluate cellular strain distributions. Ultramicroscopy 86:85-95

169. Formigli L, Meacci E, Sassoli C, Chellini F, Giannini R, Quercioli F, Tiribilli B, Squecco R, Bruni P, Francini F, Zecchi-Orlandini S (2005) Sphingosine 1-phosphate induces cytoskeletal reorganization in $\mathrm{C} 2 \mathrm{C} 12$ myoblasts: physiological relevance for stress fibres in the modulation of ion current through stretch-activated channels. J Cell Sci 118:1161-1171

170. Huang S, Ingber DE (2005) Cell tension, matrix mechanics, and cancer development. Cancer Cell 8:175-176

171. Suresh S (2007) Biomechanics and biophysics of cancer cells. Acta Biomater 3:413-438

172. Campbell DH (1890) Studies in cell-division. Bull Torrey Bot Club 17:113-121

173. Oviatt BL (1887) Cardiac muscle cells in man and certain other mammals. Proc Am Soc Microsc 9:283-298 